\title{
Cost-optimal technology and fuel choices in the transport sector under a stringent climate stabilization target
}

\author{
Takayuki Takeshita \\ Transdisciplinary Initiative for Global Sustainability, The University of Tokyo \\ Japan
}

\section{Introduction}

Climate change is one of the most serious challenges in the 21st century. To avoid dangerous climate change, a variety of greenhouse gas (GHG) mitigation actions have increasingly been taken in all sectors of the global energy system. The International Energy Agency (IEA) indicated that the transport sector accounted for about $23 \%$ of energy-related $\mathrm{CO}_{2}$ emissions in 2005 and is likely to have a higher share in the future unless strong action is taken (IEA, 2008). Furthermore, the IEA showed that if a halving of 2005 energy-related $\mathrm{CO}_{2}$ emissions is to be achieved by 2050, the transport sector must make a significant contribution, despite the fact that transport's central economic role and its deep influence on daily life have made rapid changes difficult to achieve (IEA, 2000, 2008). It is, therefore, critically important to find a long-term, cost-effective strategy for reducing $\mathrm{CO}_{2}$ emissions from the transport sector.

So far, several studies have been carried out to address this issue using long-term global technology-rich bottom-up energy system models, with notable examples being Azar et al. (2003), Turton (2006), IEA (2008, 2009), and Grahn et al. (2009). Although these studies investigated the future role of alternative propulsion systems and fuels in the light-duty vehicle sector under $\mathrm{CO}_{2}$ constraints, all of these studies except IEA $(2008,2009)$ did not place sufficient focus on the other modes of transport. The IEA $(2008,2009)$ derived the results for energy use and $\mathrm{CO}_{2}$ emissions in the transport sector from a number of scenarios using the model covering all modes of transport. However, these scenario results are substantially affected by arbitrary assumptions about the diffusion rates of alternative propulsion systems and fuels. Moreover, these IEA scenarios have a time horizon until 2050, rather than a time horizon until 2100 adopted in the other three previous studies cited above, which makes it difficult to assess the very long-term prospects for radically new transport technologies.

In this context, the objective of this chapter is to examine the cost-optimal choice of propulsion systems and fuels for each of 13 transport modes over the 21st century under a constraint that the long-term global mean temperature rise would be limited to 2.0 to 2.4 degrees Celsius. This chapter also presents the results of the sensitivity analysis with respect to three important factors: (1) the climate stabilization target; (2) the cost of a proton 
exchange membrane (PEM) fuel cell stack and a hydrogen storage tank; and (3) the demand for supersonic air travel. These analyses are done by using a global energy system model called REgionally Disaggregated Global Energy Model with 70 regions (REDGEM70), which describes the transport sector in detail.

The rest of the chapter proceeds as follows. Section 2 outlines the structure of the REDGEM70 model and describes how to model the transport sector. Section 3 gives key input data and assumptions for the model. The model simulation results and discussion are presented in Section 4 . Section 5 concludes the chapter.

\section{Model Descriptions}

\subsection{Overview of REDGEM70}

REDGEM70 is a bottom-up type, global energy systems optimization model with a detailed technological representation, which is formulated as an intertemporal linear programming problem. With a $5 \%$ discount rate, the model is designed to determine the optimal energy strategy for each of 70 world regions from 2000 to 2100 at 10 -year time steps so that total discounted energy system costs are minimized under constraints on the satisfaction of exogenously given useful energy and energy service demands, the availability of primary energy resources, the maximum market penetration rate of new technologies, the atmospheric $\mathrm{CO}_{2}$ concentration, etc. The model has a full flexibility in when and where $\mathrm{CO}_{2}$ emissions reductions are achieved to stabilize the atmospheric $\mathrm{CO}_{2}$ concentration at a given level.

The 70 regions of REDGEM70 are categorized into "energy production and consumption regions" and "energy production regions." The whole world is first divided into the 48 energy production and consumption regions to which future useful energy and energy service demands are allocated. The 22 energy production regions, which are defined as geographical points, are then distinguished from the energy production and consumption regions to represent the geographical characteristics of the areas endowed with large amounts of primary energy resources. Such a detailed regional disaggregation enables the explicit consideration of the regional characteristics in terms of energy resource supply, energy demands, and geography.

REDGEM70 is also characterized by a detailed description of the whole energy system, from primary energy supply through energy conversion to final energy consumption, as illustrated in Fig. 1. In the downstream part of the model, future useful energy demand trajectories are given for each of the industrial and residential/commercial sectors and decomposed by demand category, whereas future energy service demand trajectories (expressed in passenger-km ( $\mathrm{pkm}$ ) or tonne-km $(\mathrm{tkm})$ ) given for each of 13 transport modes. For each end-use demand category, the possibility of price-induced demand reductions, substitutability among final energy carriers (for example, high-quality energy carriers can be used for a wide range of applications), and changes in efficiency and costs associated with final energy substitution are considered in the model. All transport technologies, which refer to possible combinations of propulsion systems and transport fuels in this chapter, are characterized by parameters such as energy intensity, capital cost, and operating and maintenance $(\mathrm{O} \& \mathrm{M})$ cost, and their cost-optimal mix is endogenously determined for each transport mode in the model. 


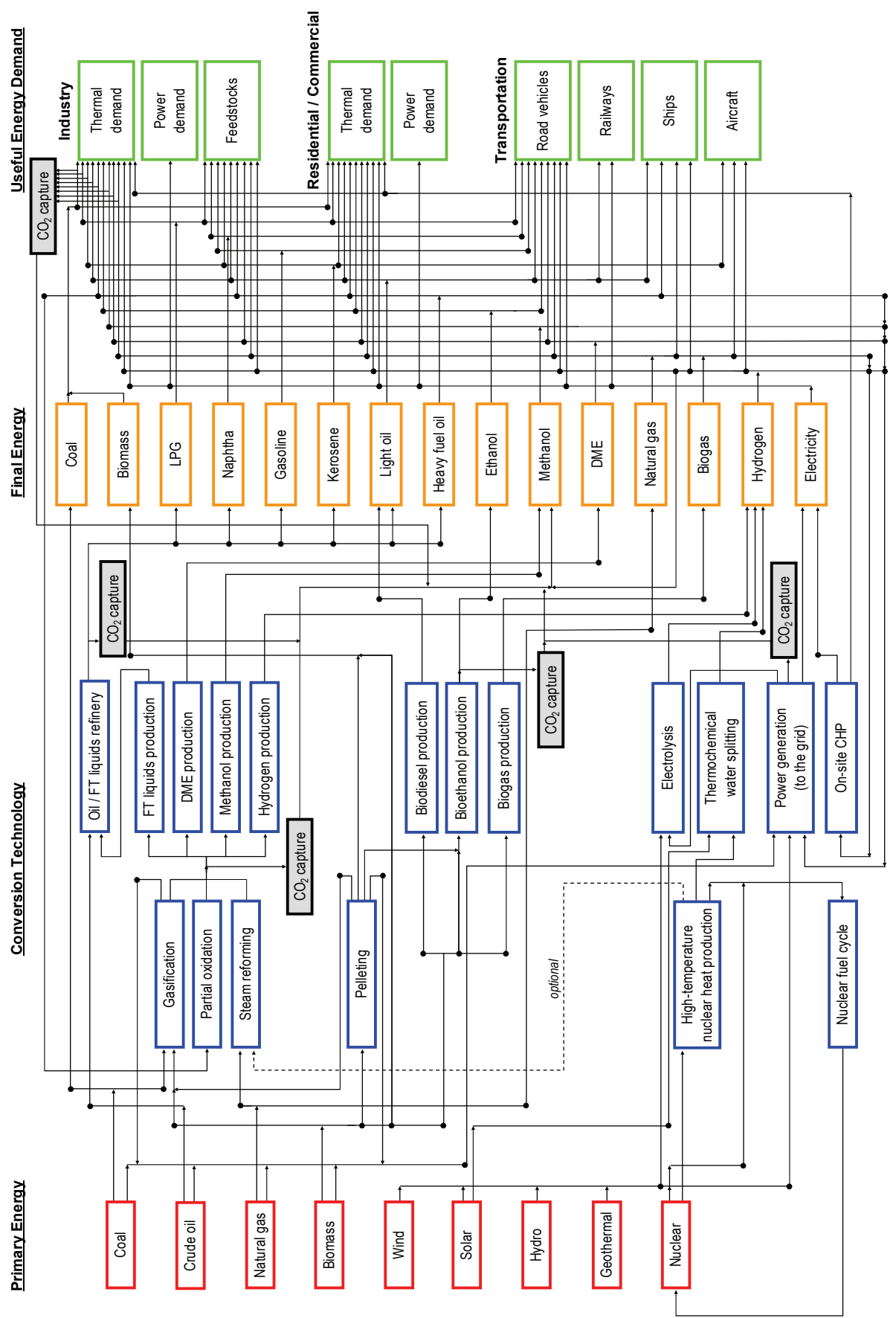

Fig. 1. Schematic representation of the structure of REDGEM70 
On the supply side, REDGEM70 considers the entire supply chain of final energy carriers, which includes primary energy production, interregional energy transportation, coastal storage, conversion into secondary energy, intraregional secondary energy distribution, and final energy supply at retail sites (e.g., refuelling). To represent the economics of each of these final energy supply chain stages in a realistic manner, the model considers the capital and O\&M costs separately at each stage of the fuel supply chain (excluding resource extraction) by treating the corresponding infrastructure explicitly. Note that final energy carriers are not always supplied in this order: a wide variety of final energy supply patterns can be selected in the model. The model treats the interregional transportation of 10 types of energy carriers and $\mathrm{CO}_{2}$ between representative cities/sites in the 70 model regions and is able to identify its cost-optimal evolution path. Furthermore, the model considers the difference in the cost of local secondary energy distribution not only by energy carrier, but also by time point, region, and end-use sector. To make such modelling possible, the spatial structure of energy production and consumption regions is represented in detail in the model by consideration of the distribution of energy system components in this type of model regions, as illustrated in Fig. 2. The inclusion of the entire supply chain of final energy carriers, the separate consideration of capital and O\&M costs across their entire supply chain, and the differentiation of intraregional secondary energy distribution costs (as described above) are three key features to help the model better represent the economics of transport fuels.

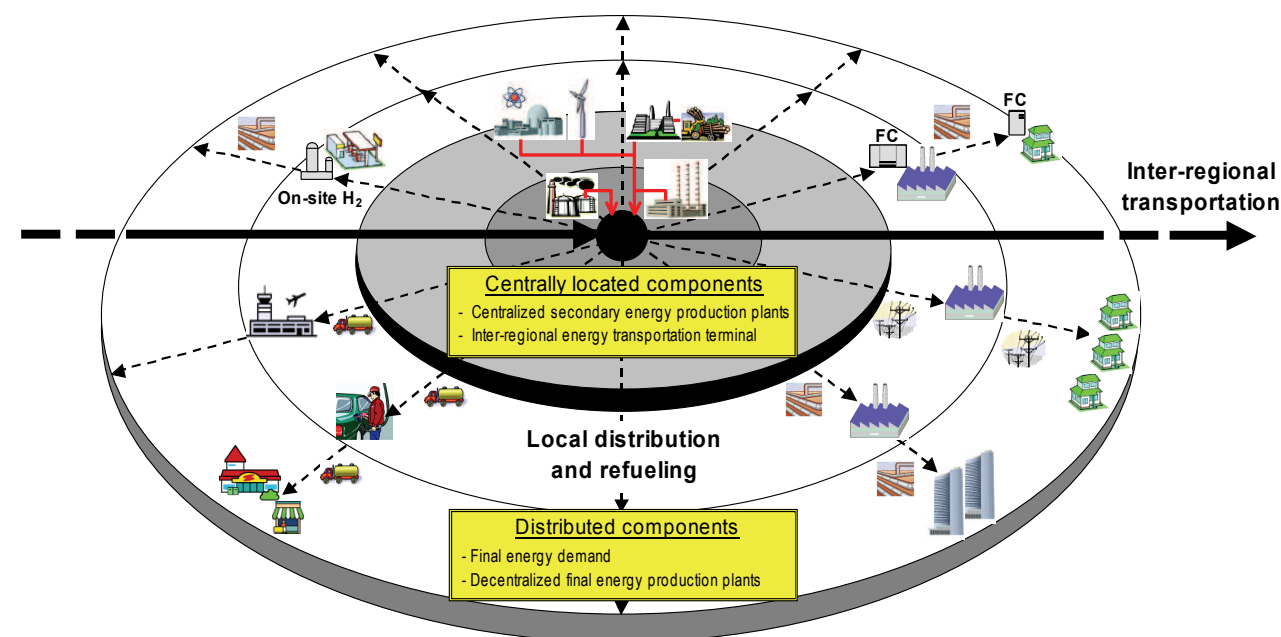

Fig. 2. Spatial structure of energy production and consumption regions in REDGEM70

REDGEM70 considers a number of promising energy conversion technologies. In particular, the model comprehensively includes technologies for producing alternative energy carriers such as synthetic fuels (i.e., hydrogen, methanol, dimethyl ether (DME), and FischerTropsch (FT) synfuels) and conventional biofuels (i.e., bioethanol, biodiesel, and biogas). For biomass resources, the model considers not only plantation biomass such as energy crops (which are defined as fast-growing trees, e.g., hybrid poplars and willows, in the model), modern fuelwood, sugar crops, grain crops, and oilseed crops, but also waste biomass. 
Given the amount of excess cropland that can be used for energy purposes, the model determines its optimal allocation among different plantation-based crop biomass productions based on crop yields per hectare of land, crop supply costs, and characteristics of conversion technologies available. The model also describes in detail the refinery process streams for crude oil and raw FT liquids, which consist of a lot of refinery processes. In the model, the $\mathrm{CO}_{2}$ generated from power plants (excluding those used for on-site combined heat and power production and biomass-fired steam cycle power production), synthetic fuels production plants (excluding those used for converting stranded gas and decentralized small-scale hydrogen production), ethanol production plants, oil/FT refinery plants, and industrial processes can be captured for subsequent sequestration in geologic formations or methanol synthesis.

\subsection{Transport sector submodel}

In REDGEM70, passenger transport modes included are motorized two-wheelers, light-duty vehicles, buses, ordinary rail, high-speed rail, subsonic aircraft, and supersonic aircraft, whereas medium-duty trucks, heavy-duty trucks, freight rail, domestic shipping, international shipping, and freight air distinguished for freight transport. To take into account the inertia of each transport mode, its capital vintage structure (i.e., age structure) is represented in the model, where vehicles other than motorized two-wheelers and light-duty vehicles produced at a certain time period exist at the next time period.

In the model, energy requirements in the transport sector are derived from transport activity (measured in pkm and $\mathrm{tkm}$ ) and actual in-use energy intensity (measured in $\mathrm{MJ} / \mathrm{pkm}$ and $\mathrm{MJ} / \mathrm{tkm}$ ). The actual in-use energy intensities of road vehicles are calculated by dividing their respective on-road fuel economy (measured in MJ per vehicle-km) by their respective average occupancy rate (measured in passenger per vehicle and tonne per vehicle), whereas those of non-road transport modes are exogenous inputs to the model. The model allows for price-induced transport activity demand reductions by incorporating the long-run price elasticity of transport activity demand.

The road traffic supply-demand constraints are given by:

$$
\operatorname{Ract}(m, i, t) \leq \sum_{s} \sum_{v} L F(m, i, t)^{*} A D T(m, i, t)^{*} \operatorname{vin}(m, s, t)^{*} V(m, v, i, s)+S(m, i, t)
$$

where $\operatorname{Ract}(m, i, t)$ is the demand for road transport (in $\mathrm{pkm} / \mathrm{tkm}$ ) carried by mode $m$ in region $i$ at time period $t ; L F(m, i, t)$ is the load factor (i.e., vehicle occupancy rate) for mode $m$ in region $i$ at time period $t ; A D T(m, i, t)$ is the annual distance travelled per vehicle (i.e., annual mileage per vehicle) for mode $m$ in region $i$ at time period $t$; $\operatorname{vin}(m, s, t)$ is the remaining rate of transport technologies of vintage $s$ available for mode $m$ in their fleet stocks at time period $t ; V(m, v, i, s)$ is the number of transport technologies $v$ available for mode $m$ produced in region $i$ at time period $s$ (which is endogenously determined in the model); and $S(m, i, t)$ is the price-induced transport activity demand reductions in mode $m$ in region $i$ at time period $t$.

On the other hand, the non-road traffic supply-demand constraints are given by:

$$
\operatorname{NRact}(m, i, t) \leq \sum_{s} \sum_{v} L F(m)^{*} \operatorname{vin}(m, s, t)^{*} C A P(m, v, i, s)+S(m, i, t)
$$


where $\operatorname{NRact}(m, i, t)$ is the demand for non-road transport (in $\mathrm{pkm} / \mathrm{tkm}$ ) carried by mode $m$ in region $i$ at time period $t$ and $C A P(m, v, i, s)$ is the capacity of transport technology $v$ available for mode $m$ produced in region $i$ at time period $s$, which is defined in terms of pkm per year or tkm per year and is endogenously determined in the model. In this equation, domestic shipping is classified into two modes: large ships and small ships.

\section{Data and Assumptions}

\subsection{Scenario driving forces}

Future trajectories for scenario driving forces such as population, gross domestic product measured in purchasing power parities $\left(\mathrm{GDP}_{\mathrm{ppp}}\right)$, and end-use demands are based on the "Middle Course" case B developed by the International Institute for Applied Systems Analysis (IIASA) and the World Energy Council (WEC) (Nakicenovic et al., 1998). End-use demand projections were first made for each of 11 world regions used in the IIASA/WEC study (Nakicenovic et al., 1998). They were then disaggregated into the 48 energy production and consumption regions of REDGEM70 by using country- and state-level statistics/estimates (and projections if available) on population, $\mathrm{GDP}_{\mathrm{ppp}}$, geography, energy use by type, and transport activity by mode, and by taking into account the underlying storyline of the case $\mathrm{B}$ that regional diversity might be somewhat preserved throughout the 21st century. Note that throughout this chapter, an 11-region classification is identical to that of the joint IIASA/WEC study (Nakicenovic et al., 1998).

Future transport activity demands were projected for each of the 13 transport modes and each of the 11 world regions mainly based on Victor (1990), Azar et al. (2000, 2003), Schafer \& Victor (2000), and Fulton \& Eads (2004). Fig. 3 shows the resulting passenger and freight transport activity demand projection by mode at the global level. Domestic ship transport is carried out by large and small ships. The share of each ship type in total domestic shipping activity was set for each of the 11 world regions based on Fulton \& Eads (2004).
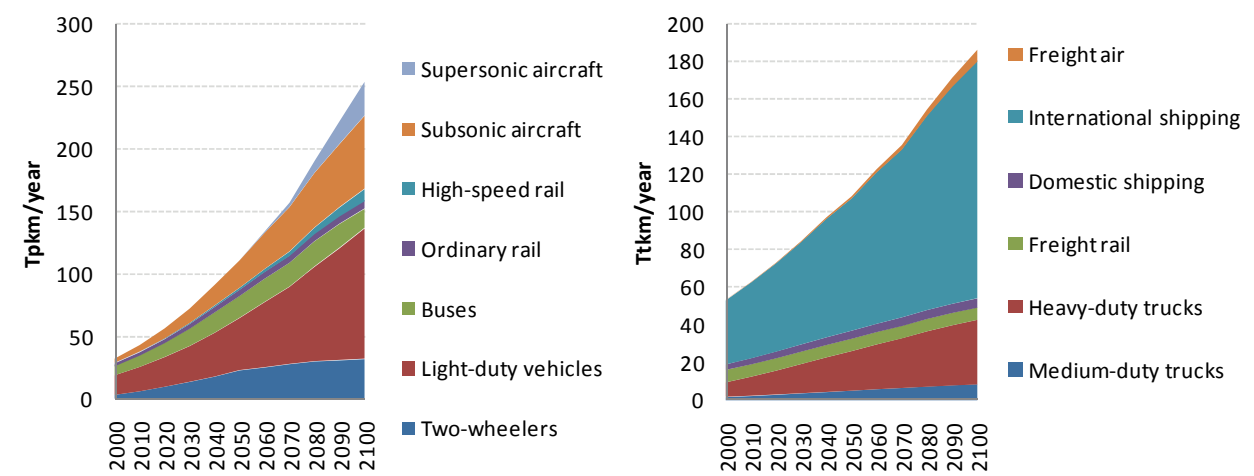

Fig. 3. Projected global passenger (left) and freight (right) transport activity demand

\subsection{Delivered costs for transport fuels}

This section focuses on the data and assumptions for the intraregional distribution and refuelling of transport fuels. A detailed description of the data and assumptions for the 
other stages of the final energy supply chain is given in Takeshita \& Yamaji (2008) and Takeshita $(2009,2010)$. Table 1 shows the intraregional distribution and refuelling costs for each transport fuel. It is implicitly assumed that the intraregional distribution of CNG and $\mathrm{GH}_{2}$ is made by pipeline and that liquid transport fuels are distributed intraregionally by truck, except that the distribution of LNG and $\mathrm{LH}_{2}$ to airports is by rail. For the supply of LNG or $\mathrm{LH}_{2}$ to aircraft, two possible pathways are considered: (1) the receipt of CNG/GH via pipeline at an airport boundary followed by the liquefaction of natural gas/hydrogen and the supply of $\mathrm{LNG} / \mathrm{LH}_{2}$ to aircraft; and (2) the receipt of $\mathrm{LNG} / \mathrm{LH}_{2}$ via rail at an airport boundary followed by the supply of LNG/ $\mathrm{LH}_{2}$ to aircraft (Brewer, 1991).

\begin{tabular}{|c|c|c|}
\hline Transport fuel & $\begin{array}{l}\text { Intraregional } \\
\text { distribution cost } \\
\text { (USD/GJ) }\end{array}$ & $\begin{array}{l}\text { Refuelling } \\
\text { cost } \\
\text { (USD/GJ) }\end{array}$ \\
\hline Petroleum and FT products & 0.8 & 1.3 \\
\hline Liquefied petroleum gas (LPG) & 1.1 & 2.1 \\
\hline Ethanol & 1.0 & 1.9 \\
\hline DME & 1.5 & 3.0 \\
\hline \multicolumn{3}{|l|}{ Liquefied natural gas (LNG) } \\
\hline LNG supply to international ocean-going ships & 0 & 4.8 \\
\hline LNG supply to aircraft & 1.8 & 4.8 \\
\hline \multicolumn{3}{|l|}{ Liquid hydrogen $\left(\mathrm{LH}_{2}\right)$} \\
\hline $\mathrm{LH}_{2}$ delivery and $\mathrm{GH}_{2}$ refuelling & 2.5 & 5.6 \\
\hline \multicolumn{3}{|l|}{$\mathrm{LH}_{2}$ delivery and $\mathrm{LH}_{2}$ refuelling } \\
\hline $\mathrm{LH}_{2}$ supply to medium-duty trucks & 2.5 & 5.0 \\
\hline $\mathrm{LH}_{2}$ supply to aircraft & 2.5 & 6.7 \\
\hline \multicolumn{3}{|l|}{ Compressed natural gas (CNG) } \\
\hline CNG supply to light-duty vehicles and heavy-duty trucks & 3.3 & 3.3 \\
\hline CNG supply to buses and medium-duty trucks & 2.0 & 3.3 \\
\hline CNG supply to aircraft & 1.3 & - \\
\hline \multicolumn{3}{|l|}{ Gaseous hydrogen $\left(\mathrm{GH}_{2}\right)$} \\
\hline \multicolumn{3}{|l|}{ Centralized $\mathrm{H}_{2}$ production } \\
\hline $\mathrm{GH}_{2}$ supply to light-duty vehicles & 4.7 & 4.7 \\
\hline $\mathrm{GH}_{2}$ supply to buses and medium-duty trucks & 2.8 & 4.7 \\
\hline $\mathrm{GH}_{2}$ supply to domestic freight ships & 1.9 & 6.3 \\
\hline $\mathrm{GH}_{2}$ supply to international ocean-going ships & 0 & 6.3 \\
\hline $\mathrm{GH}_{2}$ supply to aircraft & 1.9 & - \\
\hline Decentralized $\mathrm{H}_{2}$ production & - & 3.9 \\
\hline \multicolumn{3}{|l|}{ Electricity } \\
\hline Electricity supply to two-wheelers and light-duty vehicles & 5.1 & 5.0 \\
\hline Electricity supply to buses and medium-duty trucks & 3.1 & 5.0 \\
\hline
\end{tabular}

Table 1. Intraregional distribution and refuelling costs for transport fuels

In addition to their temporal development, REDGEM70 takes into account the site-specific feature of the intraregional distribution costs of transport fuels, in particular gaseous fuels (Azar et al., 2000). Following the approach proposed by Ogden (1999a), the intraregional distribution costs of $\mathrm{CNG}, \mathrm{GH}_{2}$, and electricity are assumed to vary depending on the density of final energy demands. They are estimated to be lower for urban areas where a geographically concentrated demand exists (Ogden, 1999a; van Ruijven et al., 2007). It is assumed that there is a high correlation between the density of final energy demands and the level of urbanization (i.e., the percentage of the population living in urban areas). By 
using this relationship and the local $\mathrm{GH}_{2}$ distribution cost function proposed by Ogden (1999a, p.252), the intraregional distribution cost of $\mathrm{GH}_{2}$ was estimated for each world region and each time period as a function of the level of urbanization. The intraregional distribution costs of CNG and electricity were estimated similarly with their world average values for the year 2000 taken into account.

In the light of the degree of spatial distribution of refuelling points for each transport mode, ranging from centralized to completely decentralized, the model considers the difference in the intraregional distribution costs of $\mathrm{CNG}, \mathrm{GH}_{2}$, and electricity by transport mode: costs of distributing them to aircraft and domestic freight ships are assumed to be $60 \%$ lower than, costs of distributing them to buses and medium-duty trucks are assumed to be $40 \%$ lower than, and costs of distributing them to motorized two-wheelers and heavy-duty trucks are assumed to be the same as those of distributing them to light-duty vehicles, whereas the intraregional distribution of transport fuels to international ocean-going ships is assumed to be unnecessary. These assumptions are based on the fact that delivery trucks and buses are usually centrally refuelled, and that long-haul heavy-duty trucks must be able to refuel at reasonable distances (IEA, 2008). The intraregional distribution costs of liquid transport fuels are assumed to be the same across all transport modes because the distribution distance has a small impact on them (Amos, 1998; Simbeck \& Chang, 2002).

The share of capital costs in total costs is assumed to be $85 \%$ for pipeline distribution and electric power transmission, whereas the corresponding estimate is $33 \%$ for truck distribution and 75\% for refuelling (Amos, 1998; Simbeck \& Chang, 2002). Considering that the major expense is not the pipeline cost itself but installing the pipeline (Amos, 1998) and that installed pipeline capital costs are site specific (Ogden, 1999a), installed capital costs of pipelines and power transmission lines by world region were calculated by applying a region-specific location factor.

\subsection{Techno-economic data and assumptions for transport technologies}

It is assumed that the average lifetime is 10 years for motorized two-wheelers and light-duty vehicles, 15 years for buses and trucks, and 20 years for trains, ships, and aircraft. Based on data from Landwehr \& Marie-Lilliu (2002), the long-run price elasticity of transport activity demand was set at -0.17 for motorized two-wheelers and light-duty vehicles, -0.18 for aircraft, -0.20 for trucks, and 0 for the other transport modes.

Fig. 4 shows the actual in-use energy intensity of a conventional reference transport technology by transport mode for the years 2000, 2050, and 2100. For the definition of a conventional reference transport technology, see footnote in Fig. 4. Note that the actual inuse energy intensity of transport technologies of the vintages of the same year as that in which they are operated is shown in these figures. 


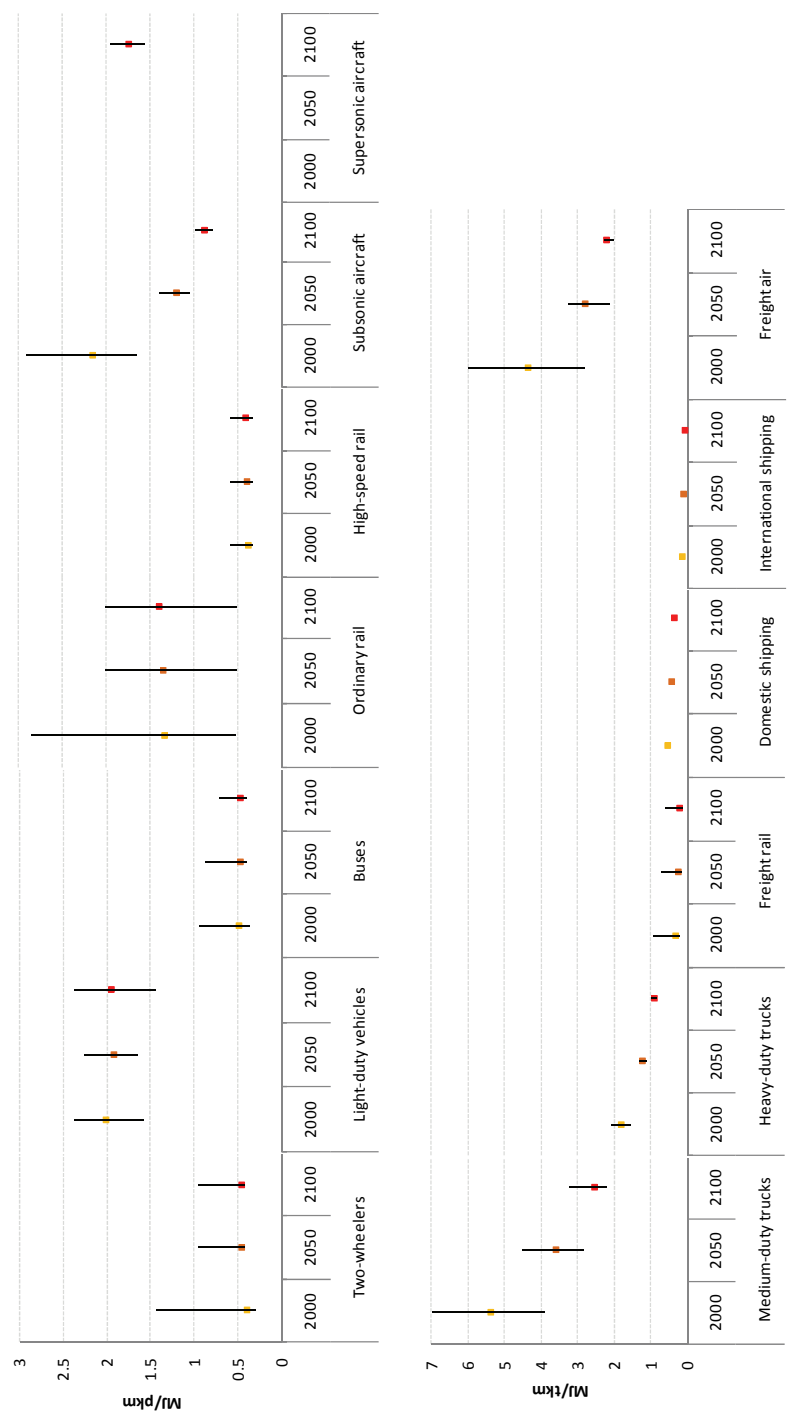

Fig. 4. Projected actual in-use energy intensities of passenger (upper) and freight (lower) transport modesa,b

a These figures show the actual in-use energy intensities of reference transport technologies.

It is assumed that the reference transport technology is a gasoline internal combustion engine (ICE) vehicle for motorized two-wheelers and light-duty vehicles, a diesel ICE vehicle for buses, trucks, non-high-speed rail, and domestic shipping, a heavy fuel oil (HFO) ICE vehicle for international shipping, and a kerosene ICE vehicle for aircraft.

$\mathrm{b}$ The world average shown as squares in these figures is calculated as the activity-weighted average of the actual in-use energy intensity of each transport mode. The range denotes the difference by world region. 
The on-road fuel economy of conventional gasoline ICE light-duty vehicles was projected for each of the 11 world regions by taking into account future improvements in their testbased fuel economy due to technical progress, recent trends (e.g., towards larger and more powerful vehicles), current and future expected policies, and the gap between their test and on-road fuel economy. Except for high-speed rail and aircraft, improved fuel efficiencies of passenger transport technologies would be offset to some small or large degree by declining vehicle occupancy rates (Schafer \& Victor, 1999; Azar et al., 2000). For high-speed rail, it is assumed that a development towards faster speeds would offset technical efficiency gains (Azar et al., 2000). In contrast, it is indicated that large reductions in the actual in-use energy intensity of aircraft are possible (Schafer \& Victor, 1999).

By conducting a comprehensive survey of literature and interviewing experts, possible combinations of propulsion systems and transport fuels were defined for each transport mode and techno-economic parameters were set for each transport technology. As an example, Table 2 shows the assumed possible combinations of propulsion systems and transport fuels for road vehicles. A hybrid propulsion system is not considered for long-haul heavy-duty trucks because they operate primarily on highways at near to maximum rated power and because hybrids are estimated to provide virtually no efficiency benefits on highway driving cycles (Fulton \& Eads, 2004). Durability is a key issue for fuel cell propulsion systems, so they are not considered for long-haul heavy-duty trucks that often travel over 100,000 km/year (IEA, 2008).

Transport technologies available for non-high-speed rail are assumed to be diesel and electric trains, while those available for high-speed rail are assumed to be high-speed electric trains and magnetic levitation (maglev) systems. Contrary to IEA (2008) and Electris et al. (2009), fuel cell propulsion systems are not considered for the non-high-speed rail sector for the same reason as in the case of heavy-duty trucks. Because the two transport technologies available for high-speed rail are powered by electricity and because the actual in-use energy intensity of the maglev systems is estimated to fall to that of high-speed electric trains (Azar et al., 2000), the electricity consumption of the high-speed rail sector is given exogenously to the model and each of the two transport technologies is not characterized in the model. As regards the freight shipping sector, transport technologies available for small ships are assumed to be diesel ICEs, diesel ICEs with electric motors, and $\mathrm{GH}_{2}$ fuel cell hybrids, while those available for large ships are assumed to be HFO ICEs, LNG ICEs with electric motors, and HFO ICEs with a $\mathrm{GH}_{2}$ fuel cell auxiliary power unit (APU).

Based on Victor (1990) and IEA (2005), it is assumed that not only kerosene-fuelled aircraft but also LNG- and $\mathrm{LH}_{2}$-fuelled aircraft are available for the subsonic aviation sector. In contrast, the supersonic aviation sector is assumed to have no $\mathrm{CO}_{2}$ mitigation options other than biomass-derived FT kerosene. This is because supersonic aircraft fly in the stratosphere $80-85 \%$ of the time, where water vapour has a far more powerful greenhouse effect than in the troposphere (Penner et al., 1999), and because the intensity of water vapour emissions, expressed as amount of emissions per unit of transport activity, is much higher for LNGand $\mathrm{LH}_{2}$-fuelled aircraft than for kerosene-fuelled aircraft (more than three times higher for $\mathrm{LH}_{2}$-fuelled aircraft than for kerosene-fuelled aircraft). Supersonic aircraft are assumed to be consistently half as energy efficient as subsonic aircraft (Victor, 1990). 


\begin{tabular}{|c|c|c|c|c|c|}
\hline $\begin{array}{l}\text { Transport } \\
\text { technology }\end{array}$ & Two-wheelers & $\begin{array}{c}\text { Light-duty } \\
\text { vehicles }\end{array}$ & Buses & $\begin{array}{c}\text { Medium-duty } \\
\text { trucks }\end{array}$ & $\begin{array}{c}\text { Heavy-duty } \\
\text { trucks }\end{array}$ \\
\hline Gasoline ICEVs & + & + & + & + & \\
\hline Diesel ICEVs & & + & + & + & + \\
\hline LPG ICEVs & & + & + & + & \\
\hline Gasohol ICEVs & + & + & + & + & \\
\hline Ethanol ICEVs & + & + & + & + & + \\
\hline DME ICEVs & & + & + & + & + \\
\hline CNG ICEVs & & + & + & + & + \\
\hline $\mathrm{GH}_{2}$ ICEVs & & + & + & & \\
\hline $\mathrm{LH}_{2} \mathrm{ICEVs}$ & & & & + & \\
\hline Gasoline HEVs & & + & + & + & \\
\hline Diesel HEVs & & + & + & + & \\
\hline LPG HEVs & & + & + & + & \\
\hline Gasohol HEVs & & + & + & + & \\
\hline Ethanol HEVs & & + & + & + & \\
\hline DME HEVs & & + & + & + & \\
\hline CNG HEVs & & + & + & + & \\
\hline $\mathrm{GH}_{2} \mathrm{HEVs}$ & & + & + & + & \\
\hline Gasoline PHEVs & & + & & + & \\
\hline Diesel PHEVs & & + & & + & \\
\hline Gasohol PHEVs & & + & & + & \\
\hline Ethanol PHEVs & & + & & + & \\
\hline Gasoline FCHVs & & + & + & + & \\
\hline DME FCHVs & & + & + & + & \\
\hline $\mathrm{GH}_{2} \mathrm{FCHVs}$ & & + & + & + & \\
\hline BEVs & + & + & + & + & \\
\hline
\end{tabular}

Table 2. Possible combinations of propulsion systems and transport fuels for road vehiclesa,b a Possible combinations of propulsion systems and transport fuels are marked by pluses (+).

b ICEVs=internal combustion engine vehicles; HEVs=hybrid electric vehicles; PHEVs=plugin hybrid electric vehicles; FCHVs=fuel cell hybrid vehicles; $\mathrm{BEVs}=$ battery electric vehicles. Gasohol is defined as a $10 \%$ ethanol to $90 \%$ gasoline volumetric blend.

Except for pure electric vehicles, the capital cost of light-duty vehicles was estimated for all alternative transport technologies that have a consumer performance (such as range, acceleration, passenger and cargo capacity) comparable to that of their conventional gasoline ICE counterpart. Based on Grahn et al. (2009) and IEA (2009), pure electric lightduty vehicles are assumed to have a driving range of $200 \mathrm{~km}$, whereas all other transport technologies available for light-duty vehicles are assumed to have a driving range of 500 $\mathrm{km}$. To compensate for such reduced driving range, pure electric vehicles are likely to require fast charging stations in cities and/or along certain corridors (IEA, 2009). Following the method of Simbeck \& Chang (2002), they were estimated to add USD 5/GJ to the delivered cost of electricity (see Table 1). Similar to Grahn et al. (2009), plug-in hybrid vehicles are assumed to operate as electric vehicles for $65 \%$ of their daily driving.

The assumptions about the specific cost of batteries (in USD/kWh) designed for road vehicles are based on IEA (2009). Li-ion batteries for pure electric light-duty vehicles with a $200 \mathrm{~km}$ range were estimated to cost USD 478/ $\mathrm{kWh}$ in 2020, and their specific cost was expected to decline to USD $330 / \mathrm{kWh}$ by 2030 . The specific cost of Li-ion batteries for pure electric buses and pure electric medium-duty trucks can be estimated from the relationship between the energy $(\mathrm{kWh})$ and specific cost of Li-ion batteries: the specific cost of Li-ion batteries for pure electric vehicles was estimated to be $13 \%$ and $10 \%$ lower for buses and 
medium-duty trucks, respectively, than for light-duty vehicles. Specific battery costs differ by vehicle type. For light-duty vehicles, the specific cost of Li-ion batteries was estimated to eventually drop to USD 460/kWh for conventional hybrids and USD 420/kWh for plug-in hybrids, respectively.

On the other hand, the specific cost of a PEM fuel cell stack (in USD/kW) was estimated to drop to USD 500/kW in 2030 and to eventually reach USD 95/kW in 2050 (IEA, 2008; Grahn et al., 2009). For hydrogen storage, the specific cost of a $\mathrm{GH}_{2}$ storage tank at a pressure of 700 bar (in USD $/ \mathrm{kg}$ ) was estimated to drop to USD $447 / \mathrm{kg}$ in 2030 and to eventually reach USD $313 / \mathrm{kg}$ in 2050 (IEA, 2005; Grahn et al., 2009), and the specific cost of a $\mathrm{LH}_{2}$ storage tank (in USD $/ \mathrm{kg}$ ) is assumed to drop to USD 313/ $\mathrm{kg}$ in 2050 (WBCSD, 2004). For the purpose of sensitivity analysis, two different values were considered for the future costs of these technologies. Under optimistic assumptions, the specific cost in 2050 was estimated to be USD $65 / \mathrm{kW}$ for a PEM fuel cell stack and USD $179 / \mathrm{kg}$ for a $\mathrm{GH}_{2} / \mathrm{LH}_{2}$ storage tank. Under pessimistic assumptions, the specific cost in 2050 was estimated to be USD 125/ kW for a PEM fuel cell stack and USD $447 / \mathrm{kg}$ for a $\mathrm{GH}_{2} / \mathrm{LH}_{2}$ storage tank. These assumptions were made based on IEA (2008) and Grahn et al. (2009).

\subsection{Climate policy scenario}

Unless otherwise noted, REDGEM70 is run under the constraint that the atmospheric concentration of $\mathrm{CO}_{2}$ will be stabilized at $400 \mathrm{ppmv}$ in 2100, which has been assumed to assure stabilization of climate change at 2.0 to 2.4 degrees Celsius by 2100 (Metz et al., 2007). The reason for the choice of this constraint is because the Intergovernmental Panel on Climate Change (IPCC) Fourth Assessment Report (Metz et al., 2007) states that avoidance of many key vulnerabilities requires temperature change in 2100 to be below 2.6 degrees Celsius above pre-industrial levels and estimates that achieving the $\mathrm{CO}_{2}$ stabilization target of 400 ppmv would be a sufficient condition for limiting the global mean temperature change below 2.6 degrees Celsius above pre-industrial levels, using a best estimate climate sensitivity of 3.0 degrees Celsius. Overshoots are allowed before 2100 in model simulations.

\section{Simulation Results and Discussion}

\subsection{Definition of simulation cases}

The five cases as defined in Table 3 are simulated with REDGEM70 to examine (1) the costoptimal choice of transport technologies under the 400 ppmv $\mathrm{CO}_{2}$ stabilization constraint, (2) the effect of future costs of hydrogen-fuelled transport technologies on the costcompetitiveness of hydrogen in the transport sector under the $400 \mathrm{ppmv} \mathrm{CO}_{2}$ stabilization constraint, and (3) the effect of the appearance of supersonic aircraft on the cost-optimal technology strategy for the transport sector under the $400 \mathrm{ppmv} \mathrm{CO}_{2}$ stabilization constraint. 


\begin{tabular}{|c|c|c|c|}
\hline Case & Climate policy & $\begin{array}{l}\text { Costs of a PEM FC stack } \\
\text { and a } \mathrm{H}_{2} \text { storage tank }\end{array}$ & $\begin{array}{l}\text { Demand for } \\
\text { supersonic aviation }\end{array}$ \\
\hline No $\mathrm{CO}_{2}$ constraint case & $\begin{array}{l}\text { No policy } \\
\text { intervention }\end{array}$ & Reference values & Reference values \\
\hline 400 ppmv case & $\begin{array}{l}\mathrm{CO}_{2} \text { stabilization at } \\
400 \mathrm{ppmv}\end{array}$ & Reference values & Reference values \\
\hline $\begin{array}{l}400 \text { ppmv case with } \\
\text { OPT assumptions on } \\
\text { hydrogen vehicles }\end{array}$ & $\begin{array}{l}\mathrm{CO}_{2} \text { stabilization at } \\
400 \text { ppmv }\end{array}$ & Optimistic values & Reference values \\
\hline $\begin{array}{l}400 \text { ppmv case with } \\
\text { PESS assumptions on } \\
\text { hydrogen vehicles }\end{array}$ & $\begin{array}{l}\mathrm{CO}_{2} \text { stabilization at } \\
400 \text { ppmv }\end{array}$ & Pessimistic values & Reference values \\
\hline $\begin{array}{l}400 \text { ppmv case without } \\
\text { the demand for } \\
\text { supersonic aviation }\end{array}$ & $\begin{array}{l}\mathrm{CO}_{2} \text { stabilization at } \\
400 \text { ppmv }\end{array}$ & Reference values & Assumed not to occur \\
\hline
\end{tabular}

Table 3. Cases considered for simulation

\subsection{Results for the entire transport sector}

Fig. 5 shows the cost-optimal mix of transport fuels at the global level. In this figure, the consumption of each transport fuel is shown for each transport mode to examine the costoptimal choice of transport technologies by transport mode. If the climate stabilization constraint is not imposed, petroleum products continue to dominate the global transport fuel consumption and the contribution of $\mathrm{CO}_{2}$-neutral transport fuels to it is very small. In contrast, the global final-energy mix of the transport sector becomes diversified in the $\mathrm{CO}_{2}$ 400 ppmv stabilization cases. Comparing the results of the no $\mathrm{CO}_{2}$ constraint and $400 \mathrm{ppmv}$ cases shows that hydrogen, electricity, biomass-derived FT synfuels, and natural gas are promising transport fuels contributing substantially to the reduction of $\mathrm{CO}_{2}$ emissions from the transport sector.

As an alternative fuel for diesel engines, FT diesel is preferred to DME because FT synfuels have an advantage over DME in that they are largely compatible with current vehicles and existing infrastructure for petroleum fuels. In all regions, biodiesel is produced from all the available amount of waste grease and oil and used in the transport sector from 2020, but its small resource potential makes the share of biodiesel negligible.

Total global transport fuel consumption in the $\mathrm{CO}_{2} 400$ ppmv stabilization cases is smaller than that in the no $\mathrm{CO}_{2}$ constraint case. This is mainly due to the deployment of highly efficient transport technologies such as conventional and plug-in hybrids in the former cases. This trend is especially evident from 2040 onward because of technical progress and discounting. However, even in these $\mathrm{CO}_{2} 400$ ppmv stabilization cases, total global transport fuel consumption begins to increase sharply from around 2070, which is caused by the increasing demand for supersonic aviation. The lack of $\mathrm{CO}_{2}$ mitigation options other than biomass-derived FT kerosene in the supersonic aviation sector and insufficient biomass supply potential are the reasons for this.

As expected, the assumptions on the costs of a PEM fuel cell stack and a $\mathrm{GH}_{2} / \mathrm{LH}_{2}$ storage tank have an evident impact on the total global hydrogen consumption of the transport sector under the $400 \mathrm{ppmv} \mathrm{CO}_{2}$ stabilization constraint. 


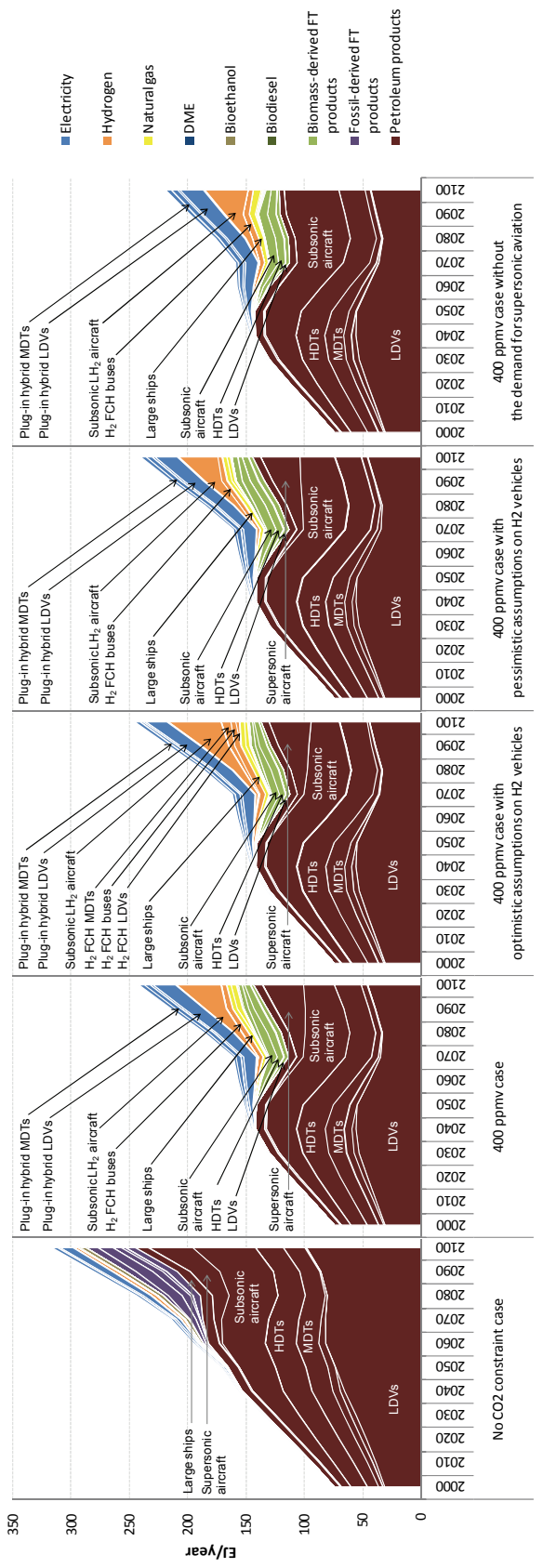

Fig. 5. Cost-optimal mix of transport fuelsa

a LDVs = light-duty vehicles; MDTs = medium-duty trucks; HDTs = heavy-duty trucks; $\mathrm{FCH}=$ fuel cell hybrid. 


\subsection{Mode-specific results}

It should be noted that the relative share of each transport fuel in total transport fuel consumption expressed in energy terms (as shown in Fig. 5) does not reflect its actual contribution to meeting the demand for transport, which can be evaluated by looking at the relative share of transport technologies running on each transport fuel in total transport activity. In the light of the relative importance of each transport mode in terms of transport activity and transport fuel consumption, Figs. 6-10 show the cost-optimal choice of transport technologies, at the global level, for the light-duty vehicle, medium-duty truck, heavy-duty truck, large ship, and passenger aviation sectors, respectively.

It can be seen from Figs. 5-10 that the cost-optimal choice of transport technologies under the 400 ppmv $\mathrm{CO}_{2}$ stabilization constraint differs significantly by transport mode. In the light-duty vehicle sector, plug-in hybrids and biomass-derived FT gasoline are selected as cost-effective $\mathrm{CO}_{2}$ mitigation options (see Figs. 5 and 6). Gasohol as well as gasoline (including FT gasoline) is the main fuel for light-duty vehicles in all cases. Regardless of the simulation cases, there is a trend in this sector that propulsion systems of choice shift from ICEs to conventional hybrids and ultimately to plug-in hybrids. In all cases, plug-in hybrids account for a large share of the total global activity of light-duty vehicles in the second half of the century. This implies that although pure electric vehicles are not selected in any case (which is also true for all other transport modes), promoting the electrification of light-duty vehicles is a robust future technology strategy. The cost-competitiveness of hydrogen fuel cell hybrid light-duty vehicles is weak, judging from the result that they could account for a tiny share toward the end of the century only in the 400 ppmv case with optimistic assumptions on hydrogen vehicles.

Fig. 5 shows that buses are a key niche market for hydrogen fuel cell (hybrid) vehicles. The first reason for this is that, as pointed out by Ogden (1999b) and IEA (2005), in the bus market cost goals for hydrogen fuel cell (hybrid) vehicles which if successfully met can insure high marketability are not as stringent as for light-duty vehicles.

In general, the share of capital costs in total lifetime costs is smaller for large commercial vehicles such as buses and trucks than it is for light-duty vehicles because the annual mileage and average lifetime of the former are longer than those of the latter. Hence, the benefits of high energy efficiency and low maintenance costs are more pronounced for large commercial vehicles. In other words, such characteristics of large commercial vehicles allow the additional capital cost to be spread over a longer period of time, which results in more favourable conditions for highly efficient, capital-intensive transport technologies such as hydrogen fuel cell (hybrid) vehicles. The second reason is that buses are centrally refuelled, which helps to overcome fuel infrastructure obstacles (IEA, 2008).

Contrary to the prior expectation, the conditions found in the bus market are not applied to the medium-duty truck market. The results in Figs. 5 and 7 reveal that the medium-duty truck sector makes the choice of transport technologies similar to that of the light-duty vehicle sector under the $400 \mathrm{ppmv} \mathrm{CO}_{2}$ stabilization constraint, except that diesel engines are preferred by the former. One explanation might be that unlike buses, the actual in-use energy intensity of diesel engine medium-duty trucks exhibits a consistently declining trend (see Fig. 4), which does not provide an adequate incentive for the uptake of highly efficient, capital-intensive hydrogen fuel cell hybrid vehicles to the medium-duty truck market. 


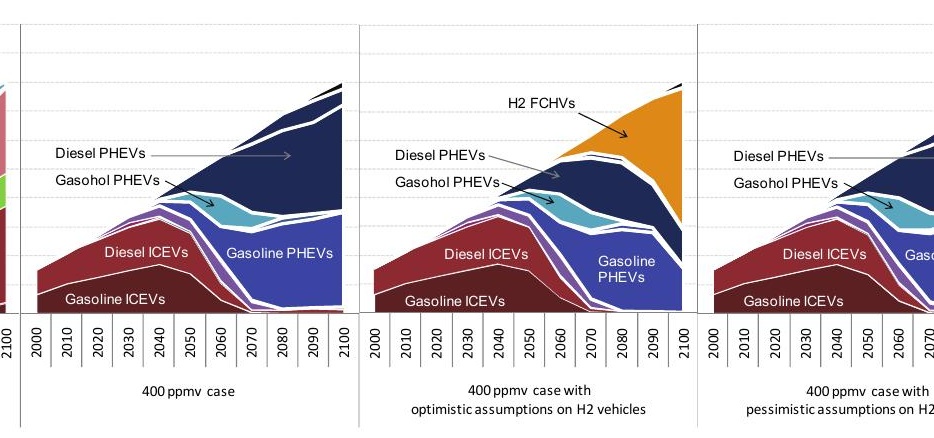




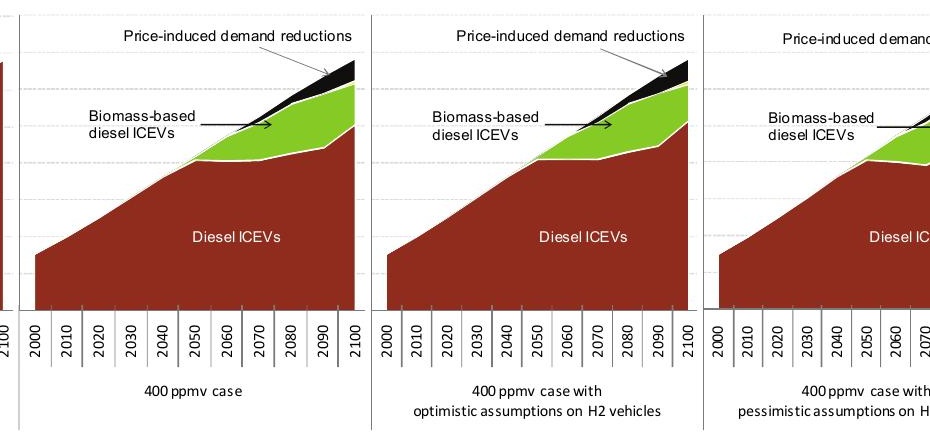




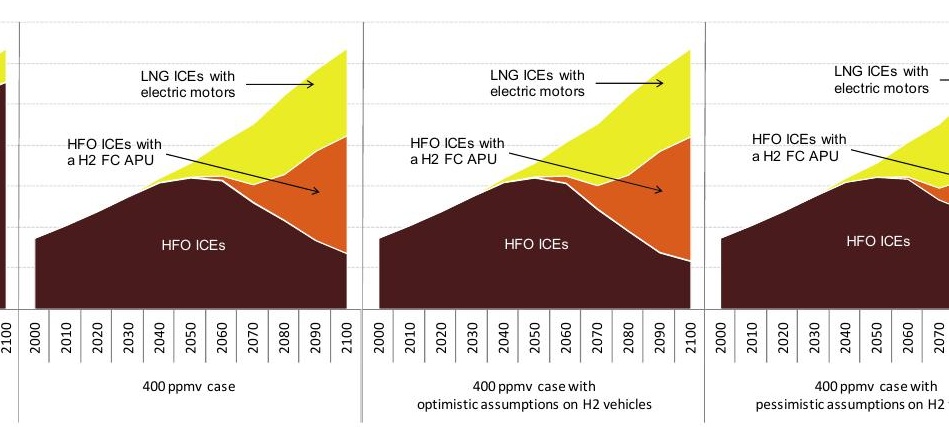



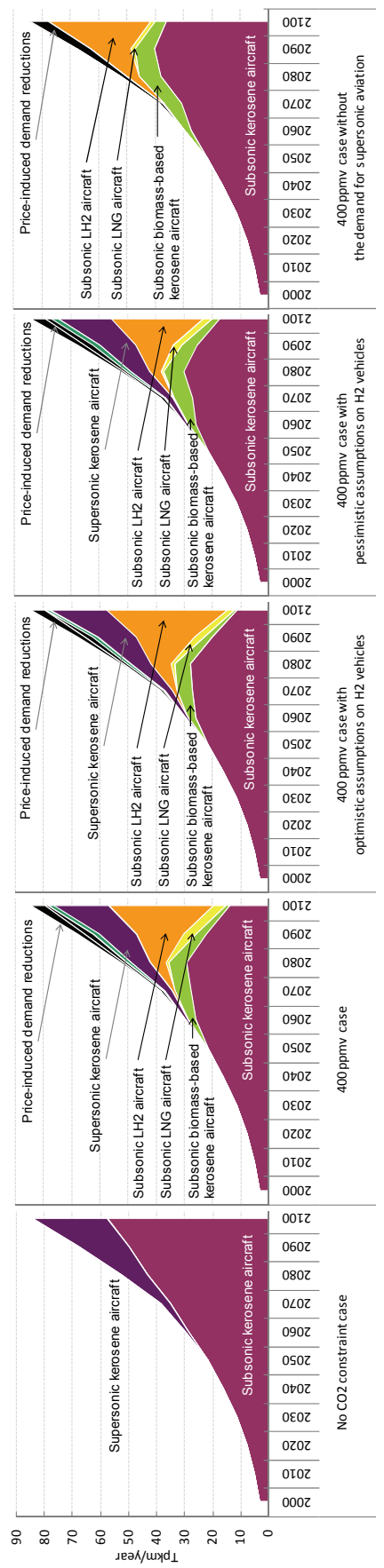

Fig. 10. Cost-optimal choice of transport technologies in the passenger aviation sector 
On the other hand, biomass-derived FT diesel is introduced into the heavy-duty truck market as a cost-effective $\mathrm{CO}_{2}$ mitigation option (see Figs. 5 and 8). Even if the 400 ppmv $\mathrm{CO}_{2}$ stabilization constraint is imposed, petroleum diesel ICEs have a dominant share of the total global activity of heavy-duty trucks. This is also mainly due to the consistently declining trend of the actual in-use energy intensity of diesel engine heavy-duty trucks. The assumption that the heavy-duty truck sector has a limited range of $\mathrm{CO}_{2}$ mitigation options is another reason for this. In the $\mathrm{CO}_{2} 400$ ppmv stabilization cases except the 400 ppmv case without the demand for supersonic aviation, the share of petroleum diesel increases toward the end of the century, which is a by-product of refinery operations to provide petroleum kerosene for the supersonic aviation sector as described below.

It is interesting to note that the results for the motorized two-wheeler sector are similar to those for the ordinary rail sector. First, energy consumption of the motorized two-wheeler and rail sectors (including the high-speed rail sector) is relatively small compared to other transport sectors because of their low actual in-use energy intensity and low levels of transport activity. Second, the share of electricity in the total global final energy consumption of each of the two sectors increases over time to significantly high levels in all cases. It should be emphasized, however, that there is a stark contrast between the costoptimal fuel mix of power generation in the $\mathrm{CO}_{2} 400$ ppmv stabilization cases and that in the no $\mathrm{CO}_{2}$ constraint case. This finding for the motorized two-wheeler sector can be regarded as reasonable because electric scooters are already very popular in China and because they are usually powered by small electric motors driven by lead-acid batteries making them the cheapest form of motorized transport in China (IEA, 2009). This finding for the ordinary rail sector suggests that the assumed autonomous trend towards the electrification of the rail system combined with the progressive decarbonisation of power generation cost-effectively reduces $\mathrm{CO}_{2}$ emissions from the ordinary rail sector on a well-to-wheel basis.

Despite very high levels of the activity of large ships, their considerably low actual in-use energy intensity resulting from the high efficiency of large, slow-speed, two-stroke engines (as much as $50 \%$ on a lower heating value basis) makes their total global final energy consumption very small. The total global final energy consumption of small ships is negligible because of their low actual in-use energy intensity and low levels of transport activity. As shown in Fig. 9, an electric propulsion system composed of LNG-fuelled ICE generators and electric motors serves as a costeffective $\mathrm{CO}_{2}$ mitigation option for large ships.

According to the results shown in Figs. 5 and 10, biomass-derived FT kerosene-fuelled and $\mathrm{LH}_{2}$-fuelled aircraft enter the subsonic passenger aviation market as cost-effective $\mathrm{CO}_{2}$ mitigation options. In the $\mathrm{CO}_{2} 400$ ppmv stabilization cases, subsonic aviation becomes the largest user of hydrogen in the transport sector toward the end of the century. The costcompetitiveness of hydrogen in the subsonic aviation sector is significantly strong toward the end of the century in the $\mathrm{CO}_{2} 400$ ppmv stabilization cases: subsonic $\mathrm{LH}_{2}$-fuelled aircraft hold a share of $65.4 \%$ in the total global activity of subsonic passenger aircraft in 2100 in the 400 ppmv case. Even when the future cost of a $\mathrm{LH}_{2}$ storage tank takes its upper bound value, subsonic $\mathrm{LH}_{2}$-fuelled aircraft account for a large share toward the end of the century under the 400 ppmv $\mathrm{CO}_{2}$ stabilization constraint. The first reason for the strong competitiveness of subsonic $\mathrm{LH}_{2}$-fuelled aircraft is that they do not suffer from the high cost of a fuel cell propulsion system. The second reason is that aircraft are centrally refuelled. The third reason is that under the stringent climate stabilization constraint, hydrogen production from biomass with $\mathrm{CO}_{2}$ capture and storage (CCS) is preferred to FT synfuels 
production from biomass with CCS because the former can sequester larger amounts of $\mathrm{CO}_{2}$. In contrast, the supersonic passenger aviation sector relies heavily on petroleum kerosene in the $\mathrm{CO}_{2} 400$ ppmv stabilization cases. This is because of the assumed unavailability of LNG and $\mathrm{LH}_{2}$ in the supersonic aviation sector, the low efficiency of supersonic aircraft, and the severe supply constraint on biomass.

\section{Conclusions}

This chapter has examined the cost-optimal choice of propulsion systems and fuels for each of the 13 transport modes over the 21st century under a constraint that the long-term global mean temperature rise would be limited to 2.0 to 2.4 degrees Celsius. It has been shown that the cost-optimal choice of transport technologies under the $400 \mathrm{ppmv} \mathrm{CO}_{2}$ stabilization constraint differs significantly by transport mode. Such a detailed analysis by transport mode is a new contribution. A future study will consider the impact of the specific cost of batteries on the cost-optimal choice of transport technologies under the stringent climate stabilization target and include non- $\mathrm{CO}_{2}$ GHGs (e.g., water vapour) in the model.

\section{References}

Amos, W.A. (1998). Costs of Storing and Transporting Hydrogen, National Renewable Energy Laboratory, NREL/TP-570-25106, Golden, CO.

Azar, C.; Lindgren, K. \& Andersson, B.A. (2000). Hydrogen or methanol in the transportation sector?, KFB, ISBN: 91-88371-90-5, Stockholm.

Azar, C.; Lindgren, K. \& Andersson, B.A. (2003). Global energy scenarios meeting stringent $\mathrm{CO}_{2}$ constraints - cost-effective fuel choices in the transportation sector. Energy Policy, Vol. 31, No. 10, 961-976, ISSN: 0301-4215.

Brewer, G.D. (1991). Hydrogen Aircraft Technology, CRC Press, ISBN: 0-8493-5838-8, Boca Raton, FL.

Electris, C.; Raskin, P.; Rosen, R. \& Stutz, J. (2009). The Century Ahead : Four Global Scenarios, Tellus Institute, Technical Documentation, Boston, MA.

Fulton, L. \& Eads, G. (2004). IEA/SMP Model Documentation and Reference Case Projection, International Energy Agency/World Business Council for Sustainable Development, Available at: <http://www.wbcsd.org/web/publications/ mobility/smp-model-document.pdf $>$.

Grahn, M.; Azar, C.; Williander, M.I.; Anderson, J.E.; Mueller, S.A. \& Wallington, T.J. (2009). Fuel and vehicle technology choices for passenger vehicles in achieving stringent $\mathrm{CO}_{2}$ targets: connections between transportation and other energy sectors. Environmental Science E Technology, Vol. 43, No. 9, 3365-3371, ISSN: 0013-936X.

IEA (International Energy Agency) (2000). World Energy Outlook 2000, IEA, ISBN: 92-6418513-5, Paris.

IEA (2005). Prospects for Hydrogen and Fuel Cells, IEA, ISBN: 92-64-109-579, Paris.

IEA (2008). Energy Technology Perspectives 2008, IEA, ISBN: 92-64-04142-4, Paris.

IEA (2009). Transport, Energy and $\mathrm{CO}_{2}$, IEA, ISBN: 978-92-64-07316-6, Paris.

Landwehr, M. \& Marie-Lilliu, C. (2002). Transportation Projections in OECD Regions, IEA, Paris. 
Metz, B.; Davidson, O.R.; Bosch, P.R.; Dave, R. \& Meyer, L.A., (Ed.) (2007). Climate Change 2007: Mitigation of Climate Change, Cambridge University Press, ISBN: 978-052170598-1, Cambridge.

Nakicenovic, N.; Grubler, A. \& McDonald, A., (Ed.) (1998). Global Energy: Perspectives, Cambridge University Press, ISBN: 0521-64569-7, Cambridge.

Ogden, J.M. (1999a). Prospects for building a hydrogen energy infrastructure. Annual Review of Energy and the Environment, Vol. 24, 227-279, ISSN: 1056-3466.

Ogden, J.M. (1999b). Developing an infrastructure for hydrogen vehicles: a Southern California case study. International Journal of Hydrogen Energy, Vol. 24, No. 8, 709730, ISSN: 0360-3199.

Penner, J.E.; Lister, D.H.; Griggs, D.J.; Dokken, D.J. \& McFarland, M. (1999). Aviation and the Global Atmosphere, Cambridge University Press, ISBN: 0521-66404-7, Cambridge.

Schafer, A. \& Victor, D.G. (1999). Global passenger travel: implications for carbon dioxide emissions. Energy, Vol. 24, No. 8, 657-679, ISSN: 0360-5442.

Schafer, A. \& Victor, D.G. (2000). The future mobility of the world population. Transportation Research Part A, Vol. 34, No. 3, 171-205, ISSN: 0965-8564.

Simbeck, D.R. \& Chang, E. (2002). Hydrogen Supply: Cost Estimate for Hydrogen Pathways Scoping Analysis, National Renewable Energy Laboratory, NREL/SR-540-32525, Golden, CO.

Takeshita, T. (2009). A strategy for introducing modern bioenergy into developing Asia to avoid dangerous climate change. Applied Energy, Vol. 86, Supplement 1, S222-S232, ISSN: 0306-2619.

Takeshita, T. (2010). Cost-optimal use of bioenergy under a stringent climate stabilization target, In: Green Energy \& Technology, Machrafi, H., (Ed.), Bentham Science Publishers, Bussum, The Netherlands (forthcoming).

Takeshita, T. \& Yamaji, K. (2008). Important roles of Fischer-Tropsch synfuels in the global energy future. Energy Policy, Vol. 36, No. 8, 2791-2802, ISSN: 0301-4215.

Turton, H. (2006). Sustainable global automobile transport in the 21st century: an integrated scenario analysis. Technological Forecasting \& Social Change, Vol. 73, No. 6, 607-629, ISSN: 0040-1625.

van Ruijven, B.; van Vuuren, D.P. \& de Vries, B. (2007). The potential role of hydrogen in energy systems with and without climate policy. International Journal of Hydrogen Energy, Vol. 32, No. 12, 1655-1672, ISSN: 0360-3199.

Victor, D.G. (1990). Liquid hydrogen aircraft and the greenhouse effect. International Journal of Hydrogen Energy, Vol. 15, No. 5, 357-367, ISSN: 0360-3199.

WBCSD (World Business Council for Sustainable Development) (2004). Mobility 2030: meeting the challenges to sustainability, WBCSD, ISBN: 2-940240-57-4, Geneva, Switzerland. 


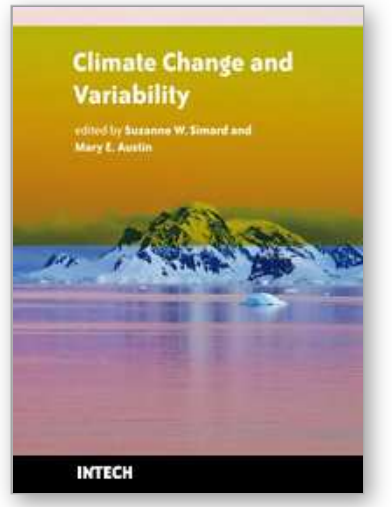

\author{
Climate Change and Variability \\ Edited by Suzanne Simard
}

ISBN 978-953-307-144-2

Hard cover, 486 pages

Publisher Sciyo

Published online 17, August, 2010

Published in print edition August, 2010

Climate change is emerging as one of the most important issues of our time, with the potential to cause profound cascading effects on ecosystems and society. However, these effects are poorly understood and our projections for climate change trends and effects have thus far proven to be inaccurate. In this collection of 24 chapters, we present a cross-section of some of the most challenging issues related to oceans, lakes, forests, and agricultural systems under a changing climate. The authors present evidence for changes and variability in climatic and atmospheric conditions, investigate some the impacts that climate change is having on the Earth's ecological and social systems, and provide novel ideas, advances and applications for mitigation and adaptation of our socio-ecological systems to climate change. Difficult questions are asked. What have been some of the impacts of climate change on our natural and managed ecosystems? How do we manage for resilient socio-ecological systems? How do we predict the future? What are relevant climatic change and management scenarios? How can we shape management regimes to increase our adaptive capacity to climate change? These themes are visited across broad spatial and temporal scales, touch on important and relevant ecological patterns and processes, and represent broad geographic regions, from the tropics, to temperate and boreal regions, to the Arctic.

\title{
How to reference
}

In order to correctly reference this scholarly work, feel free to copy and paste the following:

Takayuki Takeshita (2010). Cost-Optimal Technology and Fuel Choices in the Transport Sector under a Stringent Climate Stabilization Target, Climate Change and Variability, Suzanne Simard (Ed.), ISBN: 978-953307-144-2, InTech, Available from: http://www.intechopen.com/books/climate-change-and-variability/costoptimal-technology-and-fuel-choices-in-the-transport-sector-under-a-stringent-climate-stabiliza

\section{INTECH}

open science | open minds

\author{
InTech Europe \\ University Campus STeP Ri \\ Slavka Krautzeka 83/A \\ 51000 Rijeka, Croatia \\ Phone: +385 (51) 770447 \\ Fax: +385 (51) 686166 \\ www.intechopen.com
}

\author{
InTech China \\ Unit 405, Office Block, Hotel Equatorial Shanghai \\ No.65, Yan An Road (West), Shanghai, 200040, China \\ 中国上海市延安西路65号上海国际贵都大饭店办公楼 405 单元 \\ Phone: +86-21-62489820 \\ Fax: +86-21-62489821
}


(C) 2010 The Author(s). Licensee IntechOpen. This chapter is distributed under the terms of the Creative Commons Attribution-NonCommercialShareAlike-3.0 License, which permits use, distribution and reproduction for non-commercial purposes, provided the original is properly cited and derivative works building on this content are distributed under the same license. 